\title{
THE RIGHT TO A FAIR TRIAL AND JUDICIAL ECONOMY AT THE INTERNATIONAL CRIMINAL COURT
}

\author{
Patricia Hobbs*
}

\begin{abstract}
Following the civil unrest in Kenya in 2008 and Kenya's inability to prosecute the perpetrators of those crimes, the ICC prosecutor initiated proceedings proprio motu against $\mathrm{Mr}$ Uhuru Kenyatta and $\mathrm{Mr}$ William Ruto. Despite the impending prosecutions, Mr Kenyatta and Mr Ruto were elected as President and Deputy President of Kenya in 2013. Due to their prominent status, they both applied (separately) to be excused from continuous attendance at their trial proceedings. $\mathrm{Mr}$ Ruto's argument was heard first, and Trial Chamber (A) granted the excusal request. In the course of Mr Kenyatta's hearing by Trial Chamber (B), but before the Appeals Chamber reversed Mr Ruto's Trial Chamber (A) decision, the issue of judicial economy was raised by the prosecution. Their contention was that Trial Chamber (B) should in fact wait for the Appeals Chamber's final decision, but the Chamber dismissed the argument and proceeded with the decision at hand. This article contends that the Court missed a real opportunity to place judicial economy within the human rights discourse, particularly in the light of Article 21(3) of the Rome Statute.
\end{abstract}

\section{Keywords}

Right to a fair trial, judicial economy, trial attendance

\section{Introduction}

Following the civil unrest in Kenya in $2008^{1}$ and Kenya's inability to prosecute the perpetrators of those crimes, ${ }^{2}$ the ICC prosecutor initiated proceedings proprio motu against Mr Ruto and Mr Kenyatta. ${ }^{3}$ At the time of the relevant events, Mr Kenyatta

\footnotetext{
* Lecturer in Law, Brunel Law School, Brunel University, London, Patricia.Hobbs@ @runel.ac.uk.

1) Following the 2007-2008 contested presidential election, nearly 1,200 people died, over 350,000 were displaced, and numerous counts of rape and sexual assaults took place; see $\mathrm{G}$ Lynch and $\mathrm{M}$ Zgonec Rožej, 'The ICC Intervention in Kenya', Chatham House AFP/ILP 2013/01.

2) See P Kagwanja, 'Courting Genocide: Populism, Ethno-Nationalism and the Informalisation of Violence in Kenya's 2008 Post-Election Crisis’ (2009) 27(3) Journal of Contemporary African Studies 365 .

3) See ICC Pre-Trial Chamber II Decision Pursuant to Article 15 of the Rome Statute on the Authorization to Open an Investigation in the Situation of Kenya, ICC-01/09-19 Corr. (26 November 2009); ICC Pre-Trial Chamber II Decision Requesting Clarification and Additional Information, ICC01/09 (18 February 2010) and ICC-01/09-19 (31 March 2010).
} 
was the leader of the Party of National Unity (PNU) and Mr Ruto led the United Republican Party (URP), each representing their respective ethnic groups, the Kikuyus and the Kalenjins. ${ }^{4}$ Following the civil unrest, they formed the Jubilee Alliance, demonstrating political unity after the 2008 ethnic-centred political crisis, ${ }^{5}$ which eventually led to the 2013 Presidential election. Despite the impending ICC proceedings against them, ${ }^{6} \mathrm{Mr}$ Kenyatta was elected new President of Kenya, and $\mathrm{Mr}$ Ruto took up the role of Deputy President.

This article concerns the (separate) applications made by the two defendants, $\mathrm{Mr}$ Ruto $^{7}$ and Mr Kenyatta, ${ }^{8}$ to be excused from attending their criminal proceedings at the International Criminal Court (ICC). They argued that their prominent roles as Kenyan State officials should excuse them from attending their respective trial proceedings on a continuous basis, and therefore both applied - albeit separately - to be excused from attendance. Apart from certain limited circumstances, it is widely accepted that the defendant's presence in court is required during criminal trials in order to ensure that proceedings are conducted in such a way as to maintain the necessary high standards of fairness and justice. ${ }^{9}$

Mr Ruto's argument was heard first. After Trial Chamber (A)'s decision that he should be excused from attendance of trial proceedings, ${ }^{10}$ the case went to the Appeals Chamber, as it was believed that Trial Chamber (A) erred in law in granting Mr Ruto excusal from attendance. However, as the Appeals Chamber was deciding on this issue, ${ }^{11}$ Trial Chamber (B) was hearing the same argument with regard to $\mathrm{Mr}$ Kenyatta. Rather than waiting for the Appeals Chamber's decision, which in fact

\footnotetext{
4) See G Lynch, 'Courting the Kalenjin: The Failure of Dynasticism and the Strength of the ODM Wave in Kenya's Rift Valley Province' (2008) 107(429) African Affairs 541; S Jenkins, 'Ethnicity, Violence, and the Immigrant-Guest Metaphor in Kenya' (2012) 111(445) African Affairs 576.

5) See E Bollrich, 'Kenya's Jubilee Hangover: Torn Between Domestic Turmoil and International Affairs' (2014) International Policy Analysis.

6) Situation in the Republic of Kenya, Decision on the Confirmation of Charges Pursuant to Article 61(7)(a) and (b) of the Rome Statute, 23 January 2012, ICC-01/09-02/11-382-Red.

7) Excusal Application, Defence Request pursuant to Article 63(1) of the Rome Statute, ICC-01/0901/11-685.

8) Excusal Request, Defence Request for Conditional Excusal from Continuous Presence at Trial, ICC0109-02/11-809.

9) See Article 6(3) of the European Convention on Human Rights (ECHR) 1950; Article 14(3)(d) of the International Covenant on Civil and Political Rights (ICCPR), 1966, 999 UNTS 171.

${ }^{10)}$ Defence Request pursuant to Article 63(1) of the Rome Statute, ICC-01/09-01/11-685, ICC 01/0901/11, 18 June 2013.

11) Judgment on the appeal of the Prosecutor against the decision of Trial Chamber V(A) of 18 June 2013 entitled 'Decision on Mr Ruto's Request for Excusal from Continuous Presence at Trial', ICC 01/09-01/11 OA5, Appeals Chamber, 25 October 2013.
} 
reversed Trial Chamber (A)'s decision to excuse Mr Ruto from attendance - Trial Chamber (B) proceeded on the same issue and, just like Trial Chamber (A), granted Mr Kenyatta excusal from attendance. ${ }^{12}$ Given that the Appeals Chamber was deciding on the very same issue, the prosecution argued that it would be in line with the principle of 'judicial economy' to wait for the Appeals Chamber's decision. ${ }^{13}$ The majority of the Chamber, however, disagreed, without giving any further explanation. ${ }^{14}$ Judge Ozaki, in his partially dissenting opinion, confirmed that it is in the interests of all parties that 'proceedings are conducted efficiently and with minimal burden to the Court's system and resources'. ${ }^{15}$ Nevertheless, he agreed with the Chamber's decision to proceed given the uncertainty regarding the timing of the Appeals Chamber's decision. ${ }^{16}$

It is not straightforward to account for the Chamber's unwillingness to engage with the issue of judicial economy, or Judge Ozaki's dictum. The decision to proceed on the basis of the uncertainty surrounding the timing of the Appeals Chamber decision could, in fact, be interpreted as a precautionary measure to ensure that Mr Kenyatta's trial proceeds without undue delay, one of the elements of the right to a fair trial ${ }^{17}$. Then again, Mr Kenyatta's trial was due to start in February $2014,{ }^{18}$ he was never subject to any forms of detention during these preliminary proceedings, and all charges were eventually withdrawn. ${ }^{19}$ It seems therefore reasonable to deduce that, by following the principle of judicial economy, if Trial Chamber (B) had waited for the Appeals Chamber's decision, Mr Kenyatta would not have suffered any detrimental consequences and the decision would at least have been in line with the Appeals Chamber, which found that Trial Chamber A had erred in granting Mr Ruto the excusal from attendance.

\footnotetext{
12) Decision on Defence Request for Conditional Excusal from Continuous Presence at Trial, ICC 01/01-02-11, 18 October 2013.

13) Decision on Defence Request for Conditional Excusal from Continuous Presence at Trial ICC01/09-02/11-830, 18 October 2013, para. 34 (Kenyatta Decision).

14) Kenyatta Decision, para. 59.

15) Partially Dissenting Opinion of Judge Ozaki, ICC-01/09-02-11-830-Anx2, 18 October 2013, para. 4.

16) Ibid, para 6.

17) See Article 67(1)(c) Rome Statute.

18) The commencement of the trial was originally scheduled for 11 April 2013 ('Decision on the schedule leading up to trial', ICC-01/09-02/11, Trial Chamber V, 9 July 2012), but the date was then moved to February 2014 (Trial Chamber V(B) 'Decision adjourning the commencement of trial', 31 October 2013) but in January 2014 an order was made vacating the trial and convening a status conference (Trial Chamber V(B), ICC-01/09-02/11-886, 23 January 2014).

19) See Prosecutor v Uhuru Muigai Kenyatta, Decision on the withdrawal of charges against $\mathrm{Mr}$ Kenyatta, ICC-01/09-02/11, Trial Chamber V (B), 13 March 2015.
} 
Given that judicial economy can have an impact on the right to fair trial, this article argues that the ICC should have engaged in a more comprehensive analysis of the issue of judicial economy in order to provide a clear reasoning for the proceedings at hand rather than waiting for the Appeals Chamber's decision. The argument is framed within a specific aspect of the right to a fair trial, namely the right to be tried without undue delay, as the assumption made in this article is that there was a real concern that the delay in the proceedings would have affected Mr Kenyatta's right to a fair trial. The backdrop of this discussion is provided by a brief overview of the concept of fairness as a driving force for the right to a fair trial. This will be followed by an evaluation of the right to a fair trial, with a specific focus on the right to trial without undue delay. The section will also consider the rights-centred approach taken by the ICC, which confirms the importance to continue to develop and strengthen this aspect of the Court's activity. Lastly, the discussion will move to the concept of judicial economy, its current application by the ICC, and will put forward an argument for a wider approach in order to embed it within the right to a fair trial framework.

\section{The concept of fairness}

When the ad hoc international criminal tribunals ${ }^{20}$ were established, the protection of the defendant's rights was a reassuring and timely addition to the international criminal justice machinery. In fact, the UN Secretary-General pointed out that the tribunal (the ICTY) must 'fully respect the international recognised standards regarding the rights of the accused at all stages of its proceedings', ${ }^{21}$ with a specific focus on the rights contained in Article 14 of the ICCPR. ${ }^{22}$ However, one need to look at some of the tribunals' practices, from the illegal apprehension of alleged perpetrators, ${ }^{23}$ to decisions based on 'dubious' evidence, ${ }^{24}$ to surmise that procedural

\footnotetext{
20) International Criminal Tribunal for the Former Yugoslavia (ICTY), adopted on 25 May 1993 by Security Council Resolution 827 (1993); International Criminal Tribunal for Rwanda (ICTR), adopted on 8 November 1994 by Security Resolution 955 (1994).

21) Report of the Secretary-General pursuant to para.2 of the Security Council Resolution 808 (1993), UN Doc. S/25704, 3 May 1993, para. 106.

22) More specifically, equality before the law and a fair and impartial tribunal (Art. 14(1)); presumption of innocence (Art. 14(2)) and a variety of procedural rights in Art. 14(3), including the right to trial without undue delay.

23) For example, see Prosecutor v Slavko Dokmanović, Decision on the Motion for Release by the Accused Slavko Dokmanović, Case No. IT-95-13a-PT, T. Ch. II, 22 Oct. 1997; Prosecutor v Dragan Nikolić, Case No. IT-94-2-PT, T. Ch. II.

24) Barayagwiza v Prosecutor, Case No. ICTR -97-19-AR72, Decision, Appeals Chamber, 31 March 2000; see J Sloan, 'Breaching International Law to Ensure its Enforcement: The Reliance by the ICTY
} 
fairness, may not have been at the forefront of the tribunals' work at that time. However, international criminal justice has developed quite considerably since the establishment of the ad hoc tribunals, and fairness in trial proceedings has become a more prominent issue. ${ }^{25}$

\subsection{Fairness as an egalitarian model}

To understand the prominence of the right to a fair trial, the concept of fairness deserves some attention, starting with Rawls' perspective. He identifies fairness as

'formal justice... an aspect of the rule of law which supports and secures legitimate expectations. One kind of injustice is the failure of judges and others in authority to adhere to the appropriate rules or interpretations thereof in deciding claims'. ${ }^{26}$

According to Rawls, fairness takes on an egalitarian character, where all enjoy the same rights, irrespective of any special status in society. This egalitarian concept may be interpreted as deriving from natural law, and therefore resembling an inherent feature (and entitlement) of the human condition to seek a fair and just treatment for all. ${ }^{27}$ However, Rawls wrote his treatise with a specific kind of political structure in mind, namely a modern constitutional democracy. ${ }^{28}$ Therefore, despite the attractive feature, the egalitarian aspect of fairness, as devised by Rawls, will only apply to a specific political society, because fairness is able to make use of concepts that are naturally entrenched within institutions of a democratic government. ${ }^{29}$

With this in mind, the most obvious starting point, for the purposes of this discussion on the right to a fair trial, is the justice system itself. As Rawls declares, 'justice is the first virtue of social institutions', ${ }^{30}$ a principle that is further supported by the incorporation of the social contract theories (as put forward by Locke, Rousseau and

on Illegal Capture' in T McCormack and A McDonald (eds.), Yearbook of International Humanitarian Law (T.M.C. Asser Press, 2006).

${ }^{25)}$ See infra, page 12.

26) J Rawls, A Theory of Justice (Harvard University Press, Revised Edition, 1999), at 51.

27) See R Dworkin, Taking Rights Seriously (Harvard University Press, 1977).

28) J Rawls, 'Justice as Fairness: Political not Metaphysical' (1985) 14(3) Philosophy and Public Affairs 223.

29) Ibid, at 225.

30) Rawls, supra note 26, at 3. 
Kant) and manifested through the 'original agreement'. ${ }^{31}$ According to this theory, we all accept a universal position of equality, and we accept it because we live under a 'veil of ignorance', that is we are ignorant of our own situation, social class, status, wealth etc... This is 'justice as fairness: it conveys the idea that the principles of justice are agreed to in an initial situation that is fair' ${ }^{32}$ This system of beliefs around the concept of fairness lead to Rawls' two principles: the first one focuses on the indefeasible claims that all individuals may make, whilst the second principle puts emphasis on the fact that social and economic disadvantages should be used as opportunities rather than reasons for prejudiced treatment. ${ }^{33}$ In other words, the democratic political system of governance provides the necessary configuration for the attainment of a fair society.

Having said that, the 'original agreement' theory put forward by Rawls may be considered as too utopian to be accepted as a realistic starting point, even within a democratic system of governance as intended by Rawls. Indeed, the 'original agreement' was understood by Rawls (as well as $\mathrm{Kant}^{34}$ ) as a hypothetical situation, capable of creating the most optimum foundations for a fair system in society. The purity of this view is in fact reflected by what Rawls calls the 'veil of ignorance'. Despite the fact that it would be unrealistic to establish a society or a legal system based on the purity of this worldview, it can be argued that, in the context of international judicial bodies and practices, the 'veil of ignorance' should represent a guiding policy and a clear objective in order to ensure fair treatment to all. In the context of (international) criminal trials, a correlation of this proposition is that, by guaranteeing fairness to all, justice is achieved for all parties through a consistent and transparent application of the rules. The egalitarian model of fairness can therefore be likened to 'procedural' fairness, and this is supported by the ICC Pre-Trial Chamber I in relation to the DRC situation:

The term "fairness" (equité), from the Latin "equus", means equilibrium, or balance. As a legal concept, equity, or fairness, "is a direct emanation of the idea of justice". Equity of the proceedings entails equilibrium between the two

\footnotetext{
31) Ibid, at 10.

32) Ibid, at 11.

33) Ibid, 42-44.

34) I Kant, Groundwork for the Metaphysics of Morals (edited and translated by A. Wood, Yale University Press, 2002).
} 
parties, which assumes both respect for the principle of equality and the principle of adversarial proceedings. In the view of the Chamber, fairness of the proceedings includes respect for the procedural rights of the Prosecutor, the Defence, and the Victims as guaranteed by the relevant statutes (in systems which provide for victim participation in criminal proceedings). ${ }^{35}$

\subsection{Fairness through legitimacy}

International tribunals have often suffered from a perceived lack of legitimacy, from the Tadic challenge in relation to the establishment of the ICTY, ${ }^{36}$ to the discretion exercised by the ICC prosecutor in relation to decisions to prosecute selected situations and/or perpetrators. ${ }^{37}$ With this in mind, Frank develops the concept of fairness from a different perspective. ${ }^{38}$ According to Frank, fairness ' ... is the product of social context and history, ${ }^{39}$ and comprises of two specific elements: legitimacy and distributive justice. ${ }^{40}$ Legitimacy entails the creation and application of mechanisms, which must be perceived as fair by the participants. ${ }^{41}$ In the context of criminal justice, the implication is that participants (including the victims) are in fact able to contribute to the establishment of, and evaluate, the rules and processes that make up the legal institutions. This democratic process brings legitimacy to the system. ${ }^{42}$ Distributive justice looks at the same issue, but from a different angle. It concerns the appropriate allocation of power (included judicial power) to legal institutions if the perception is that those institutions deliver outcomes that are fair to all. In other words, distributive justice is concerned with the coherent application and consequences of these rules. ${ }^{43}$

\footnotetext{
35) ICC PTC I, Situation in the DRC, ICC-01/04, 'Decision on the Prosecutor's application for leave to appeal the Chamber's decision of 17 January 2006 on the applications for participation in the proceedings of VPRS 1, VPRS 2, VPRS 3, VPRS 4, VPRS 5 and VPRS 6', 31 March 2006, para. 38.

36) Prosecutor $\mathrm{v}$ Tadić, Decision on the Defence Motion for Interlocutory Appeal on Jurisdiction, IT94-1-T, 2 October 1995.

37) See OHCHR, 'Making Peace our Own: Victims' Perceptions of Accountability, Reconciliation and Transitional Justice in Northern Uganda' (OHCHR, Geneva 2007).

${ }^{38)}$ TM Franck, Fairness in International Law and Institutions (Clarendon Press, 1995).

${ }^{39)}$ Ibid, at 14 .

40) Ibid, at 7-9.

${ }^{41)}$ Ibid.

42) M Glacius, 'Do International Criminal Courts Require Democratic Legitimacy?' (2012) 23(1) EJIL 43.

${ }^{43)}$ Ibid; see also J Sunshine and TR Tyler, 'The Role of Procedural Justice and Legitimacy in Shaping Public Support for Policing' (2003) 37(3) Law \& Society Review 513, at 517.
} 
The legitimacy aspect of fairness is not limited to the defendant's perception of fairness with regard to procedural rules, but should also be extended to the victims and other relevant parties, including prosecutors. ${ }^{44}$ In other words, all participants must perceive the creation, allocation and use of power by the legal institutions as fair. It becomes, therefore, an exercise of neutral objectivity; indeed, 'judicial virtues such as impartiality and considerateness are the excellences of intellect and sensibility that enable us to do things well'. ${ }^{45}$ It is among the most traditional judicial characteristics, to be objective, impartial and considerate, and to administer the law in a manner that does not create inequalities amongst different classes of defendants.

Nevertheless, international judges (just like domestic ones), may be motivated by a variety of external factors, which could in fact represent a significant factor in the way decisions are taken. As Stephan argues:

Knowing that they can be replaced, the members of the [international] tribunal have an incentive not to do anything that will upset the countries with nominating authority. In those cases where the members nonetheless veer off in an unanticipated direction, the nominating state can institute a course correction within a relatively short period of time by choosing 'sounder' candidates for the tribunal. Thus one should not expect ambitious, systematic, and comprehensive law coming from an institution endowed with the authority to develop unified law on an international level. ${ }^{46}$

The existence of any competing interests would have an undesirable impact on the application of substantive and procedural fairness, and it would also cast a shadow of doubt on the legitimacy of international tribunals. Yet, the argument about the possible presence of any competing interests has its basis on the Principal-Agent theory, whereby the Principal - the State - may be able to exercise a certain amount of influence on the Agent - the appointed international judge. ${ }^{47}$ In practice, however, this is not an easy premise to validate ${ }^{48} \mathrm{~A}$ more adequate theory - and one that is in

\footnotetext{
44) See Y McDermott, 'Rights in Reverse: A Critical Analysis of Fair Trial Rights under International Criminal Law' in W Schabas et al (eds.) The Ashgate Research Companion to International Criminal Law (Ashgate, 2012).

45) Rawls, supra note 26, at 453.

46) PB Stephan, 'Courts, Tribunals and Legal Unification - The Agency Problem' (2002) 3(2) Chicago Journal of International Law 333, at 337-8.

47) KJ Alter, 'Agents or Trustees? International Courts in their Political Context' (2008) 14(1) European Journal of International Relations 33.

48) G Garrett, 'The Politics of Legal Integration in the European Union' (1995) 49(1) International Organization 171; for a contrasting view see also JHH Weiler, 'The Transformation of Europe' (1991) 100(8) Yale Law Journal 2403.
} 
line with the aims of international justice - is the Trustee-Principal theory. ${ }^{49}$ Unlike the agent, who has more autonomy but may feel bound by certain contractual obligations between him and the state, the trustee enhances

...the legitimacy of political decision-making. Trustees are (1) selected because of their personal reputation or professional norms, (2) given independent authority to make decisions according to their best judgment or professional criteria, and (3) empowered to act on behalf of a beneficiary. ${ }^{50}$

In fact, one of the most encouraging characteristics of the Trustee-Principal theory is the underlying fiduciary relationship that exists between the trustee and the main actor, in this case the state. And it is precisely this fiduciary relationship that enhances the trustworthiness of the judicial decision-making process, thus reducing the possibility of abuse of power and maintaining legitimacy. ${ }^{51}$ This theory finds support amongst many academics, including Posner and Yoo, ${ }^{52}$ who contend, in fact, that judicial effectiveness at the international level can only be maintained if there exists a certain level of 'dependency' between the judges and the appointing state. They also argue that the typical independent domestic model finds no realistic application in the international context due to the complex political interplay ${ }^{53}$ Helfer and Slaughter, on the other hand, point to the limitations of their argument that independent judges endanger international courts' effectiveness, citing specifically the weaknesses of their methodology. They put forward a theory of 'constrained independence', according to which, the state demonstrates its credibility towards international commitments, but then uses other mechanisms to limit the power of judicial decisions. ${ }^{54}$

However, it can be argued that the emerging disparities regarding judicial legitimacy are essentially due to the different perspectives taken by the aforementioned

\footnotetext{
49) Alter, supra note 47 , at 35 .

50) Ibid.

51) R Grant and R Keohane, 'Accountability and Abuses of Power in World Politics' (2005) 99(1) American Political Science Review 29.

52) EA Posner and JC Yoo, 'Judicial Independence in International Tribunals' (2005) 93(1) California Law Review 1.

53) Ibid, at 13. Posner and Yoo contend that the distinction between 'dependent' and 'independent' tribunals is based on the notion that the former are typically ad hoc international tribunals controlled by governments, either through appointment or retaliation (p. 14); 'independent' tribunals, on the other hand, reflect the domestic model and, due to their 'moral ideals' (p. 7), they pose a risk to international relations.

54) LR Helfer and A-M Slaughter, 'Why States Create International Tribunals: A Response to Professors Posner and Yoo' (2005) 93 California Law Review 901.
} 
academics. The rational-choice theory perspective, generally advocated by Posner and Yoo, ${ }^{55}$ contends that international law is not real law because it does not have a direct and independent effect on state's behavior. According to rational-choice theorists, states act rationally to maximize their interests. ${ }^{56}$ Although this approach has attracted quite a lot of criticism, ${ }^{57}$ the issue of compliance has become a traditional (and at times controversial) topic of study in international law. ${ }^{58}$ The reality of existing political forces, and the corresponding state's interests, cannot be completely ignored, but the objective of international criminal justice, namely to end impunity for international crimes, retains its legal rules and procedures. And it is the fair and just application of these rules and procedures that reiterates the traditional legal argument about compliance, and whether international law is said to be real law. Put in a different way, Posner and Yoo, and others, approach the issue of fairness within international courts using a top-down model. On the other hand, a more traditional perspective, represented by Helfer and Slaughter above, adopts a bottom-up approach. Their starting point and analysis are different, but both models contend that the existence of a fiduciary relationship (between the state and the international tribunal) enhances both the 'dependent' and 'independent' tribunals, thus furthering fairness through legitimacy.

\section{The Right to a Fair Trial}

\subsection{Setting the context}

Although the right to a fair trial has evolved significantly over the past decades, it has been part of the fundamental guarantees for centuries. Early references to fair trial procedures can be dated back to the Lex Duodecim Tabularum (the Law of the Twelve Tables) in 450 B.C., the first written laws of the Roman Republic. ${ }^{59}$ Some of the principles expressed at that time can be said to represent the forerunners to the modern procedural rights to a fair trial, namely that all parties to the dispute have the

\footnotetext{
55) Goldsmith can also be added as an advocate of this theory; see, for example, J Goldsmith and E Posner, The Limits of International Law (OUP, 2005).

56) Ibid, at 7.

57) See A von Aaken, 'To Do Away with International Law? Some Limits to 'The Limits of International Law' (2006) 17(1) EJIL 289; DF Vagts, 'International Relations Looks at Customary International Law: A Traditionalist's Defence’ (2004) 15(5) EJIL 1031.

58) See, for example, M Koskenniemi, From Apology to Utopia: The Structure of the International Legal Argument (OUP, 2005).

59) See <http://avalon.law.yale.edu/ancient/twelve_tables.asp > accessed 25 January 2016.
} 
right to be present at the hearing, ${ }^{60}$ the principle of equality ${ }^{61}$ and the principle against bribery of officials. ${ }^{62}$

The Magna Carta constitutes another development in the right to a fair trial, as it set out the principle that the law of the land curbed the power for all, including the sovereign king's, establishing the principle that all are equal before the law. ${ }^{63}$ This document, however, must be interpreted as a product of its time, as the king was in fact the only lawmaker of the land. ${ }^{64}$ Notwithstanding this, the Magna Carta - and specifically the provision that no free man can be imprisoned without the lawful pronouncement of his peers - was destined to become the cornerstone of the right to a fair trial, and started a trend that culminated in modern times. ${ }^{65}$ In fact, the wellestablished significance of the right to fair trial in international and domestic law is evidenced by its increased use in case law in the latter part of the $20^{\text {th }}$ century and the beginning of the $21^{\text {st }}$ century. ${ }^{66}$ This trend is indicative of an increasingly more balanced relationship between the state and the citizen, and reflects the model of authority that the state intends to exercise over its citizens, giving substance to principle of equality of arms. ${ }^{67}$

Notwithstanding the above, the right to a fair trial has not always been interpreted and applied in a just and coherent manner, even in modern times. For example, Justice Murphy of the U.S Supreme Court, in his dissenting opinion in the criminal trial against General Yamashita, captured the incorrect understanding of this right, namely that the right to a fair trial is not

An uncurbed spirit of revenge and retribution, masked in formal legal procedure for purposes of dealing with a fallen enemy commander, can do more lasting harm than all of the atrocities giving rise to that spirit. The people's faith in the fairness and objectiveness of the law can be seriously undercut by that spirit. ${ }^{68}$

\footnotetext{
60) Ibid, Table I (3).

61) Ibid, Table IX (1).

62) Ibid, Table IX (3).

${ }^{63)}$ A Lyon, Constitutional History of the United Kingdom (Cavendish Publishing, 2003) at 39.

64) Ibid.

65) See P Robinson, 'The Right to a Fair Trial in International Law, with Specific Reference to the Work of the ICTY' (2009) 3 Berkley J. Int. L. Publicist 1.

66) I Langford, 'Fair Trial: The History of an idea' (2009) 8(1) Journal of Human Rights 37.

67) D Robertson, A Dictionary of Human Rights (London: Europa Publications, 2004).

${ }^{68)}$ In re Yamashita, 327 U.S. 1, 1946, at 46.
} 
Therefore, irrespective of the appalling atrocities that the defendant is charged with, fairness and objectivity provide the framework for the rules that must apply before and during trial, thus avoiding a spirit of revenge and retribution. That being said, international criminal tribunals did not initially set out to make 'human rights' an inclusive part of the criminal process. For example, although references to a fair trial were included in the Charters for the International Military Tribunals established after World War II, ${ }^{69}$ they seem to point mainly towards a procedural fairness, and the IMTFE Charter appears to also allow for a great deal of restrictions of these fair procedures, thus widening judicial discretion. ${ }^{70}$ It was in fact the establishment of the ad hoc international criminal tribunals for the Former Yugoslavia (ICTY) and Rwanda (ICTR) that heralded a more contemporary phase to human rights protection of the accused in international criminal trials. In line with Articles 9 and 14 of the International Covenant of Civil and Political Rights (ICCPR), the ICTY and ICTR statutes incorporate basic rights that the accused individual is entitled to. ${ }^{71}$ It was also conceded by the UN Secretary General that 'it is axiomatic that the International Tribunal must fully respect internationally recognised standards regarding the rights of the accused at all stages of proceedings' ${ }^{72}$

\subsection{The guarantee of a trial without undue delay}

Given the well-documented concerns about the inefficiency of international criminal tribunals ${ }^{73}$ the practice of judicial economy may help the courts to focus their efforts in a structured and principled manner, thus ensuring speedy trials whilst safeguarding the defendant's rights. In other words, efficiency and rights' protection are not to be viewed as competing concepts, but as mutually supportive components of the criminal justice machinery for the sole purpose of ensuring the achievement of timely and

\footnotetext{
${ }^{69)}$ See Article 16 of the United Nations Charter of the International Military Tribunal - Annex to the Agreement for the prosecution and punishment of the major war criminals of the European Axis ('London Agreement'), 8 August 1945, 82 UNTS 279 (1945) (henceforth the Nuremberg Charter) and Article 9 of the International Military Tribunal for the Far East, T.I.A.S. 1589, 4 Bevans 20, 19 January 1946 (henceforth IMTFE Charter).

${ }^{70)}$ See Article 9 (d) and (e).

${ }^{71)}$ Specifically, Articles 20 and 21 ICTY Statute and Articles 19 and 20 ICTR Statute; also note that Article 13 ICTY and Article 12 ICTR specifically require experts in human rights law within the judiciary.

${ }_{72)}$ Report of the Secretary General Pursuant to Paragraph 2 of Security Council Resolution 808 (1993), UNSC S/25704, 3 May 1993.

${ }^{73)}$ See A Mundis, 'Improving operations in International Criminal Tribunals' (2000) 94(4) AJIL 759. However, it can also be argued that the complex nature of these cases is a contributing factor to the reduced efficiency levels; see S Ford, 'Complexity and Efficiency at International Criminal Courts' (2014) 29 Emory International Law Review 1.
} 
effective justice. This is not a new concern. It is an issue, for example, that has preoccupied the Council of Europe for a number of years. ${ }^{74}$ In fact, according to a large study undertaken by the European Commission for the Efficiency of Justice, the effectiveness of the human rights protection machinery established by the European Convention of Human Rights (ECHR) ${ }^{75}$ depends, inter alia, on the timely management of cases. ${ }^{76}$

To this end, the majority of human rights legislation, at both domestic and international level, includes the right to trial without undue delay, or within a reasonable time. ${ }^{77}$ In order to make a determination that this guarantee has been infringed, courts will consider several factors, including the length of the delay, the complexity of the proceedings, the conduct of the relevant authorities, the conduct of the accused and the prejudice to the accused. ${ }^{78}$ This is a well-established practice within the jurisprudence of the European Court of Human Rights and it therefore serves as a yardstick for other international tribunals. ${ }^{79}$ Moreover, in General Comment No. 13, the Human Rights Committee (HRC) clarified the meaning of 'trial within a reasonable time', or 'without undue delay', and specified that the

guarantee relates not only to the time by which a trial should commence, but also the time by which it should end and judgment be rendered; all stages must take place "without undue delay". To make this right effective, a procedure must be available in

\footnotetext{
${ }^{74)}$ See the European Commission for the Efficiency of Justice (CEPEJ), 'Length of court proceedings in the member states of the Council of Europe based on the case-law of the European Court of Human Rights', 6-8 December 2006 (henceforth, CEPEJ study)

${ }^{75)}$ European Convention for the Protection of Human Rights and Fundamental Freedoms, as amended by Protocols 11 and 14, 4 November 1950.

76) CEPEJ study, supra note 74, at 28.

77) See Article 14(3)(c) of the International Covenant on Civil and Political Rights (ICCPR), Article 67(1)(c) of the Rome Statute, Articles 20(4)(c) and 21(4)(c) of the Statutes of the International Criminal Tribunals for Rwanda (ICTR Statute) and for the former Yugoslavia respectively (ICTY Statute), Article 7(1)(d) of the African Charter on Human and Peoples' Rights, Article 8(1) of the American Convention on Human Rights (ACHR) and Article 6(1) of the European Convention on Human Rights and Fundamental Freedoms (ECHR).

78) See The Prosecutor v Bizimungo et al., Decision on Jérôme-Clément Bicamumpaka's Motion Seeking Permanent Stay of Proceedings, Case No. ICTR-99-50-T, 27 February 2009, para. 9; see also Y McDermott, Fairness in International Criminal Trials (OUP, 2016), at 53.

${ }^{79)}$ See Hadjikostova v Bulgaria, application no. 36843/97, 4 December 2003, para. 35; Süßmann v Germany, application no. 20024/92, 16 September 1996, Reports of Judgments and Decisions 1996-IV, para. 48, and Frydlender v France [GC], application no. 30979/96, para. 43, ECHR 2000-VII.
} 
order to ensure that the trial will proceed "without undue delay", both in first instance and on appeal. ${ }^{80}$

Therefore, any long delays between the defendant's arrest and the commencement of the trial, especially for serious crimes, cannot be justified on the basis of general problems encountered by the state following a coup d'état; this delay would amount to a violation of Article 14 (3) (c) ICCPR ${ }^{81}$ Likewise, a delay between a Court of Appeal decision and the final outcome can amount to a violation of Article 14 (3) (c), ${ }^{82}$ as well as a delay of over four years between conviction and dismissal on appeal, without valid justifications. ${ }^{83}$ The overall approach taken by the HRC, however, is that each case is evaluated on its own merits, ${ }^{84}$ echoing the approach taken by the European Court of Human Rights. ${ }^{85}$ Moreover, a trial without undue delay or within a reasonable time, must also serve the interests of justice, in the sense that it impacts not only on the defendant but also on the overall criminal justice process, as evidenced by the HRC in General Comment 32:

The right of the accused to be tried without undue delay, provided for by article 14, paragraph 3(c) ICCPR, is not only designed to avoid keeping persons too long in a state of uncertainty about their fate and, if held in detention during the period of the trial, to ensure that such deprivation of liberty does not last longer than necessary in the circumstances of the specific case, but also to serve the interests of justice. ${ }^{86}$

With this perspective in mind, the Appeals Chamber for the Special Court for Sierra Leone (SCSL) ${ }^{87}$, with reference to Article 14 ICCPR, confirmed that the right gives a guarantee to the defendant, but also added that

...for international human rights law it offers a vital and concomitant guarantee to victims of war crimes and crimes against humanity...Victims and relatives of victims

\footnotetext{
80) Human Rights Committee, General Comment 13, Article 14 (Twenty-first session, 1984), Compilation of General Comments and General Recommendations Adopted by Human Rights Treaty Bodies, U.N. Doc. HRI/GEN/1/Rev.1 at 14 (1994), para. 10.

81 ) Sandy Sextus v Trinidad and Tobago, Communication No. 818/1998, U.N. Doc. CCPR/C/72/D/818/1998 (2001), para.7.2.

${ }^{82)}$ Abdool Saleem Yasseen and Noel Thomas v Republic of Guyana, Communication No. 676/1996, U.N. Doc. CCPR/C/62/D/676/1996 (31 March 1998), para. 7.11.

83) Girjadat Siewpersaud et al v Trinidad and Tobago, Communication No. 938/2000, U.N. Doc. CCPR/C/81/D/938/2000 (2004), para. 6.2

${ }^{84)}$ Ibid, para. 6.1.

${ }^{85)}$ See Pelissier v France 25444/94 [1999] ECHR 17 (25 March 1999), para. 67.

86) Human Rights Committee, General Comment 32, Article 14: Right to equality before courts and tribunals and to a fair trial, U.N. Doc. CCPR/C/GC/32 (2007), para. 35.

87) Agreement between the United Nations and the Government Of Sierra Leone on the Establishment of a Special Court for Sierra Leone, 2178 UNTS 138; UN Doc. S/2002/246, 16 January 2002.
} 
are entitled to have those accused of hideous offences which have caused them so much grief to be tried expeditiously. Similarly, the international community which establishes special courts expects them to work expeditiously as well as fairly. That justice delayed is justice denied is no less true for being a truism. ${ }^{88}$

Notwithstanding the above, it must be acknowledged that international criminal trials are generally very complex by their very nature, and therefore can be very lengthy ${ }^{89}$ At times, it is the defendant himself who seeks to either obstruct or delay proceedings, ${ }^{90}$ a practice that can be further aggravated by the right to selfrepresentation. ${ }^{91}$ However, the actual process of gathering evidence can represent a real obstacle in itself, and therefore adding to the complexity of the trial, ${ }^{92}$ which is additionally impaired by the actual amount of evidence occasionally produced. ${ }^{93}$

\section{Fair trial at the International Criminal Court}

\subsection{The Rome Statute recognition of the right to a fair trial}

Despite previous attempts to incorporate fair trial standards and procedures, it is the Rome Statute that truly integrates these standards within its criminal procedure, ensuring that the defendant is afforded the same level of rights' protection as he or she would receive in a domestic criminal trial. For the International Criminal Court (ICC), this is not just about the concept of fair trial but it is also about the legitimacy of the court itself. ${ }^{94}$ The spirit of revenge and retribution may have characterised the first international criminal trials, ${ }^{95}$ whereas the $a d$ hoc tribunals may be remembered as a collective response to the failure of the international community to stop the atrocities

\footnotetext{
88) Prosecutor v Norman et al., Decision on the Application for a Stay of Proceedings and Denial of Right to Appeal, SCSL-2003-08-PT (4 November 2003), para. 8.

${ }^{89)}$ See G Boas, The Milošević Trial: Lessons for the Conduct of International Criminal Proceedings (CUP, 2007).

90) See Prosecutor v Norman et al., Decision on Prosecution Motion for a Ruling on the Admissibility of Evidence, SCSL-04-14-PT (24 May 2005).

91) MP Scharf, 'Self-Representation versus Assignment of Defence Counsel before International Criminal Tribunals' (2006) 4(1) JICJ 31.

92) MS Ellis, 'Achieving Justice Before the International War Crimes Tribunal: Challenges for the Defense Counsel' (1997) 7(2) Duke Journal of Comparative and International Law 519.

93) See Situation in the Republic of Kenya, Prosecutor v Ruto et al., Urgent Defence Application for Postponement of the Confirmation Hearing and Extension of Time to Disclose and List Evidence, ICC01/09-01/11, 11 august 2011, para. 3

94) D Luban, 'Fairness to Rightness: Jurisdiction, Legality, and the Legitimacy of International Criminal Law' in S Besson and J Tasioulas (eds.) The Philosophy of International Law (OUP, 2010) at 579.

${ }^{95)}$ See V Gehring (ed.), The Ethical Dimensions of Global Development (Rowman \& Littlefield, 2005) at 11 .
} 
unfolding on our television screens. ${ }^{96}$ The ICC, however, is fundamentally different in nature from its ad hoc predecessors. It is a permanent treaty-based international court, established through the sovereign states' aspiration to end impunity for international crimes. As such, the ICC had to satisfy specific criteria in relation to state sovereignty. In other words, it must guarantee, inter alia, that its criminal procedures will echo the legitimate mandate given to it by consenting sovereign states.

There is, therefore, a strong correlation between the mandate given to the ICC, and the emerging standards expected in international criminal law proceedings. These are the standards accepted by the international community, represented in this context by the member states to the Rome Statute. The fair rules are therefore linked to the international community, ${ }^{97}$ because it is the international community that gives them legitimacy through the ratification process. The ICC, in turn, achieves legitimacy through compliance with well-established international human rights laws applied by the same sovereign states that consented to extending their traditional criminal jurisdiction to the ICC. Its legitimacy, therefore, is bolstered by the inclusion of several rights of the accused, starting with the protection of the defendant's rights during investigative proceedings, ${ }^{98}$ to the Trial Chamber assurance that the trial will be fair and expeditious, ${ }^{99}$ to the presumption of innocence, ${ }^{100}$ and to extensive rights of the accused during the actual trial. ${ }^{101}$

\subsection{Article 21 (3) of the Rome Statute and 'internationally recognised human rights'}

Article 21 (3) of the Rome Statute stipulates that 'the application and interpretation of law pursuant to this article must be consistent with internationally recognized human rights...'. The content of this article represents the willingness of state parties to give the utmost assurance to defendants that the ICC may even be obligated to set aside rules that may conflict with international human rights norms. This is indeed a significant provision, and has been likened to a superior norm, ${ }^{102}$ even to the point of

\footnotetext{
96) See G Gagnon et al, 'The Collective International Responsibility to Protect: The Case of Darfur' (2005) 4(1) Northwestern Journal of International Human Rights 118.

97) See Franck, supra note 38.

98) Article 55 Rome Statute.

99) Article 64 Rome Statute.

100) Article 66 Rome Statute.

101) Article 67 Rome Statute.

102) A Pellet, 'Applicable Law' in Antonio Cassese et al (eds), The Rome Statute of the International Criminal Court: A Commentary Vol. II (OUP, 2002) at 1079.
} 
amounting to a norm possessing a constitutional character, according to some academics. ${ }^{103}$ It can also be asserted that this provision may in fact confer more powers to the court than originally conceived, ${ }^{104}$ thus allowing the ICC chambers to widen their interpretation of the applicable law, ${ }^{105}$ though there is no consensus yet on this point.

In the Lubanga case, ${ }^{106}$ Judge Pikis stated that customary international law and international treaties represent strong indicators of the status of internationally recognised human rights'. As such, the right to a fair trial, according to his opinion, would qualify as an 'internationally recognised human right'. ${ }^{107}$ The complexity of the International Criminal Court, however, should not be underestimated, especially as it deals with national laws, regional and international treaties, and other decisions, in order to find the correct interpretation to a provision that may be considered to be too vague. ${ }^{108}$ As Sheppard writes:

Uncertainty with respect to the Court's applicable law imposes a great burden on all parties. Each of the Prosecutor, Defense, Victims' Representatives, Public Counsel and Registry will, in all likelihood, have to make submissions on the powers and obligations of the Court in light of its human rights obligations at some point. Without foreknowledge of what those obligations are, or even how to determine what they are, participants cannot tailor their submissions, nor meaningfully plan ahead with a clear sense of how a dispute may be resolved. ${ }^{109}$

Having said that, the groundbreaking approach of Article 21 (3) confirms that a human rights-centric approach will guide the interpretation and application of the law, and the Appeals Chamber in the Lubanga case confirms this:

Article 21(3) of the Statute stipulates that the law applicable under the Statute must be

${ }^{103)}$ W Schabas, The International Criminal Court: A Commentary on Rome Statute (OUP, 2010), at 398.

104) MH Arsanjani, 'The Rome Statute of the International Criminal Court' (1999) 93(1) AJIL 22, at 28.

105) J Powderly, 'The Rome Statute and the Interpretative Corseting of the Interpretative Judicial Function' in C Stahn (ed.) The Law and Practice of the International Criminal Court (OUP, 2010), 485. 106) The Prosecutor v Thomas Lubanga Dyilo, ICC-01/04-01/06-424, Decision on the Prosecutor's "Application for Leave to Reply to 'Conclusions de la defenseen reponse au memoire d'appeal du Procureur"”, Separate Opinion of Judge Georghios M Pikis (12 September 2006) (ICC, A.Ch.).

107) Ibid, para. 3.

108) See D Sheppard, 'The International Criminal Court and "Internationally Recognized Human Rights": Understanding Article 21(3) of the Rome Statute' (2010) 10(1) International Criminal Law Review 43.

109) Ibid, at 44. 
interpreted as well as applied in accordance with internationally recognized human rights. Human rights underpin the Statute; every aspect of it, including the exercise of the jurisdiction of the Court. Its provisions must be interpreted and more importantly applied in accordance with internationally recognized human rights; first and foremost, in the context of the Statute, the right to a fair trial, a concept broadly perceived and applied, embracing the judicial process in its entirety... Where fair trial becomes impossible because of breaches of the fundamental rights of the suspect or the accused by his/her accusers, it would be a contradiction in terms to put the person on trial. Justice could not be done. A fair trial is the only means to do justice. If no fair trial can be held, the object of the judicial process is frustrated and the process must be stopped. ${ }^{110}$

Although the context of this dictum is about the manner in which evidence had been obtained, it can clearly be applied to any procedure that may infringe the rights of the accused, and therefore compromise the fairness of the judicial process. A correlation of this argument is that the interpretation of article 21(3) can expand the rights of the accused, as the Appeals Chamber found in the Lubanga case. The Court decided that procedural impropriety could trigger a stay of proceedings, ${ }^{111}$ even if this specific procedure is not incorporated in the rights of the accused under Article 67 of the Rome Statute. ${ }^{112}$ Despite the fact that this wider interpretation of Article 21 (3) may yield a positive outcome, it can also produce incoherent ones, as demonstrated in the Katanga case. ${ }^{113}$ Here the Trial Chamber, for the first time, set aside a specific provision of the Rome Statute, as its application would have led to an inconsistent application of internationally recognized human rights. ${ }^{114}$

In this context, the 'internationally recognised human right' in need of protection related to the right to seek asylum, in line with, inter alia, the 1951 Geneva Convention, the Protocol of 31 January 1967 relating to the Status of Refugees,

\footnotetext{
110) The Prosecutor v Thomas Lubanga Dyilo, ICC-01/04-01/06-772, Judgment on the Appeal of Mr Thomas Lubanga Dyilo against the Decision on the Defense Challenge to the Jurisdiction of the Court pursuant to Article 19(2)(a) of the Statute of 3 October 2006 (14 December 2006) (ICC, A.Ch.), para. 37.

111) Ibid, para. 39.

112) See C Stahn (ed.), The Law and Practice of the International Criminal Court (OUP, 2015), 486488.

113) The Prosecutor v Germaine Katanga and Mathieu Ngudjolo Chui, ICC-01/04-01/07, Decision on an Amicus Curiae application and on the "Requête tendant à obtenir présentations des témoins DRCD02-P-0350, DRC-D02-P-0236, DRC-D02-P-0228 aux autorités néerlandaises aux fins d'asile" (articles 68 and 93(7) of the Statute), TC, 9 June 2011.

${ }^{114)}$ Ibid, para. 73.
} 
Article 14 of the 1948 Universal Declaration of Human Rights and the principle of non-refoulement. ${ }^{115}$ Article 93(7) Rome Statute allows the Court to request the transfer and custody of a person for the purposes of identification or for giving evidence or other assistance, but the witnesses must be returned to the requested state as soon as the objective of the transfer has been satisfied. It is therefore a provision that could, albeit temporarily, deprive a person of his/her freedom. In the Katanga case, the ICC detained three witnesses after completion of their testimony, which was argued to be in contravention of their rights to liberty and effective remedy, in accordance with Articles 5 and 13 of the European Convention on Human Rights (ECHR). ${ }^{116}$

After three years of detention, the Appeals Chamber ${ }^{117}$ decided that, in fact, the ICC had no jurisdiction to detain the three witnesses and that it was solely the Dutch Government's responsibility to grant them the asylum application for an effective remedy. ${ }^{118}$ The Appeals Chamber concluded that the Court should have never refused to comply with its obligations under Article 93(7), as this would jeopardise its cooperation agreement with its member states. ${ }^{119}$ As such, Article 21(3) cannot be interpreted in a manner that is contrary to the nature of the court, being a judicial body and not an administrative detention unit for asylum seekers. ${ }^{120}$ In other words, the Court's authority to detain individuals (in accordance with Article 93(7)) is limited to instances that are related to the Court's judicial proceedings. ${ }^{121}$ The Court must, therefore, interpret its obligations under Article 93(7) in conformity with Article $21(3) .^{122}$

This course of action is further supported by the decision of the Pre-Trial Chamber II concerning the Prosecution's application to dismiss in limine the Victims' request for review of the Prosecution's decision to temporarily suspend active investigation in the

\footnotetext{
${ }^{115)}$ Ibid, para.67.

116) International Justice Monitor, Lawyers Bring Petition Against the Dutch State for Unlawful Detention of Congolese Witnesses in ICC Trial, 7 September 2012, at <http://www.ijmonitor.org/2012/09/lawyers-bring-petition-against-the-dutch-state-for-unlawfuldetention-of-congolese-witnesses-in-icc-trial> accessed 10 February 2016.

117) Situation in the Democratic Republic of the Congo in the case of the Prosecutor v Mathieu Ngudjolo Chui, Order on the implementation of the cooperation agreement between the Court and the Democratic Republic of the Congo concluded pursuant article 93 (7) of the Statute, ICC-01/04-02/12A, 12 January 2014.

118) Ibid, para. 24.

119) Ibid, para. 26.

120) Ibid, para. 27.

121) Ibid.

122) Ibid, para. 30.
} 
Kenya situation, due to lack of cooperation from Kenya. ${ }^{123}$ It was clearly stated in this case that the Pre-Trial Chamber does not have the power to review the Prosecutor's decisions, and therefore there is no need to resort to Article 21(3) as an alternative interpretative tool, ${ }^{124}$ much to the disagreement of the victims' group. ${ }^{125}$ Although it is possible to review the ICC Prosecutor's decision when it concerns a determination not to investigate a referred situation, ${ }^{126}$ the Rome Statute is silent in relation to the review of a prosecutor's decision to terminate an on-going prosecution. ${ }^{127}$

Remarkably, the language used in the victims' group response is evocative of one of the most prominent regional human rights instruments, namely the European Convention of Human Rights. ${ }^{128}$ The Rome Statute is compared to a living instrument, and it therefore requires that 'its provisions be interpreted and applied so as to make its safeguards practical and effective'. ${ }^{129}$ If the Rome Statute is indeed a living instrument, then it must be capable of evolving according to new challenges, and Article 21(3) may indeed represent a new challenge with respect to the manner in which fair procedures are interpreted and applied. There is in fact an argument that Article 21(3) raises international human rights to a 'standard against which all the law applied by the Court should be tested', ${ }^{130}$ leading to Article 21(3) conceivably becoming an 'overarching framework' of supra-legality, and even resembling the character of a jus cogens norm. ${ }^{131}$ Though the Court does not have explicit jurisdiction to set aside provisions of the Rome Statute or even to re-interpret them in a manner that was not envisaged during the negotiation process, the full impact of Article 21(3) is yet to be seen. Nevertheless, the Rome Statute provisions in relation

\footnotetext{
${ }^{123)}$ ICC Kenya Situation, Prosecution's application to dismiss in limine the Victims' request for review of Prosecution's decision to cease active investigation, Pre-Trial Chamber II, ICC-01/09, 25 August 2015 (Dismissal of victims' request).

${ }^{124)}$ Ibid, para. 52.

125) ICC Kenya Situation, Victims' response to Prosecution's application to dismiss in limine the Victims' request for review, Pre-Trial Chamber II, ICC-01/09, 15 September 2015 (Victims' response). 126) Articles 53 (2) (c), 53 (3) (a) and (b) Rome Statute.

127) In fact, it was the difficult circumstances in relation to the lack of cooperation that prevented effective investigations (Dismissal of victims' request, fn. 82, para. 24)

See also C Stahn, 'Judicial review of prosecutorial discretion: five years on' in C Stahn and G Sluiter (eds.), The Emerging Practice of the International Criminal Court (OUP, 2009), at 270-273.

${ }^{128)}$ See G Letsas, 'The ECHR as a Living Instrument: its meaning and legitimacy' in A Føllesdal et al (eds.), The European Court of Human Rights in a National, European and Global Context (CUP, 2013).

129) Victims' response, supra note 125, para. 13.

${ }^{130)} \mathrm{G}$ Bitti, 'Article 21 and the Hierarchy of sources of Law before the ICC' in C Stahn (ed.), The Law and Practice of the International Criminal Court (OUP, 2015), at 434.

131) A Pellet, 'Applicable Law' in A Cassese et al, The Rome Statute of the International Criminal Court: A Commentary (Vol. II) (OUP, 2002), at 1081.
} 
to fair trial, and the inclusion of Article 21(3), point towards the recognition of the centrality of human rights within this international criminal law regime. It is within this context that the discussion now moves towards an evaluation of the concept and use of judicial economy by the ICC, and its place within the human-rights centred approach adopted by the Court.

\section{Fitting judicial economy within the right to a fair trial framework}

\subsection{Defining the scope of judicial economy}

The discussion at the beginning of this article revealed that Trial Chamber (B) dealt with the concept of 'judicial economy' in a fleeting manner. Whilst allowing the hearing concerning Mr Kenyatta's excusal from trial proceedings, the Appeals Chamber was about to overturn Trial Chamber (A) decision concerning Mr Ruto's excusal from attending his trial proceedings. In other words, there was no debate that would provide a logical rationale to justify the Court's proceedings to go ahead. The discussion on the right to a fair trial, presented in the previous sections of this paper, places the Court in a very positive light, and clearly demonstrates its commitment to protect the rights of all parties. But how does judicial economy fit within this framework?

As international prosecutions can be very lengthy and expensive, budget concerns have become more prominent as the international community continues to maintain its commitment to ending impunity for international crimes. From the costly ad hoc tribunals for the Former Yugoslavia and Rwanda, ${ }^{132}$ to the permanent International Criminal Court and to the establishment of hybrid tribunals, the international community has experimented with different forms of international justice in order to demonstrate its commitment (and duty) towards effective prosecutions. ${ }^{133}$ Judicial economy can be succinctly summarised as '[e]fficiency in the management of a particular litigation or the courts in general...[and]...measures taken to avoid unnecessary effort or expense on the part of the court or the court system'. ${ }^{134}$ It comes to no surprise, therefore, that this principle has been widely adopted by international

\footnotetext{
132) R Zacklin, 'The Failings of Ad Hoc International Criminal Tribunals' (2004) 2(2) Journal of International Criminal Justice 541.

${ }^{133)}$ For an in-depth discussion on the budgetary resources of the different international tribunals see $\mathrm{M}$ Wierda and A Triolo, 'Resources' in L Reydams et al (eds.) International Prosecutions (OUP, 2012).

134) J Wallace and SE Wild, Webster's New World Law Dictionary, 2006, at 164.
} 
courts, even though it is occasionally used as a strategic and political tool to satisfy member states. ${ }^{135}$

The specific procedures aimed at supporting judicial economy do not need to be explicitly incorporated in international instruments, as they are part of fundamental canons of adjudication, ${ }^{136}$ and judges are indeed expected to make use of this principle. ${ }^{137}$ The principles of res judicata and lis pendens represent some of the manifestations of judicial economy, and at the same time they embody the essence of a criminal trial. Essentially, 'with respect of the same crimes, there must not be two or more criminal trials simultaneously (lis pendens), or successively (...res judicata)' ${ }^{138}$ Notably, some international instruments have explicitly incorporated them in their admissibility procedures ${ }^{139}$, and given proliferation of international tribunals, it is even more essential to strengthen the practice of judicial economy in order to avoid, at the very least, conflicting outcomes. ${ }^{140}$

In addition to the provision of a framework for judicial economy, these procedural mechanisms also contribute to the framework of the right to a fair trial, as they specifically protect defendants from overzealous prosecutorial practice. By the same token, it can be argued that there are certain elements of the concept of judicial economy that may sit uneasily within the right to a fair trial, as efficiency could compromise this fundamental right, though the right to be tried without undue delay needs to fit within this framework. Therefore, expeditiousness of proceedings can be considered as an element of the right to be tried without undue delay, though it is not to be evaluated independently.

There are other mechanisms, which, although not entirely part of the judicial economy framework, aim to expedite trials to ensure the right to be tried without

\footnotetext{
${ }^{135)}$ ML Busch and KJ Pelc, 'The Politics of Judicial Economy at the World Trade Organization' (2010) 64(2) International Organization 257; see also LR Helfer and A Slaughter, 'Why States Create International Tribunals: A Response to Professors Posner and Yoo' (2005) 93(3) California Law Review 1 , at 51 .

136) FM Palombino, 'Judicial economy and the limitations of the scope of the decision in international adjudication' (2010) 23(4) Leiden Journal of International Law 909, at 910.

137) Ibid.

138) G Sluiter et al (eds.) International Criminal Procedure - Principles and Rules (OUP, 2013), at 436.

139) For example, Article 9 of the Dispute Settlement Understanding of the World Trade Organization (WTO) and Article 35 (2)(b) ECHR; see also S Flogaitis et al (eds.), The European Court of Human Rights and its Discontent: Turning Criticism into Strength (Edward Elgar, 2013).

140) A Reinitsch, 'The use and limits of res judicata and lis pendens as procedural tools to avoid conflicting dispute settlement outcomes' (2004) 3(1) The Law and Practice of International Courts and Tribunals 37.
} 
undue delay. For example, it is widely known that some of the pre-trial practices adopted by the ad hoc ICTY and Rwanda tribunals led to appallingly (and costly) lengthy trials, mainly due to the combination of the inquisitorial and accusatorial practices embedded in the Rules of Procedure and Evidence (RPE). ${ }^{141}$ These pre-trial procedures have conceivably affected both the partiality of proceedings ${ }^{142}$ as well as the fairness to the accused due to lack of adequate funding for the defence team and lack of state cooperation with regard to the gathering of evidence. ${ }^{143}$ With this in mind, Higgins has put forward some proposals to ensure fairness and expediency of pre-trial stage: first, an Independent Investigative Commission should be appointed to carry out investigations for both the defence and the prosecution, thus maintaining fairness and transparency. ${ }^{144}$ She also proposes an increased judicial intervention at the pre-trial stage of proceedings, specifically aiming at the management of the indictments, ${ }^{145}$ as well as the provision of more resources for the defence. ${ }^{146}$

Some of these proposals to enhance fairness of proceedings can be seen in practice. For instance, the ICC has imposed the duty on the prosecutor to search for and disclose any exculpatory evidence, ${ }^{147}$ has given enhanced powers to the Pre-Trial Chamber, ${ }^{148}$ and has included victim participation 'in a manner which is not prejudicial to or inconsistent with the rights of the accused and a fair and impartial trial'. ${ }^{149}$ With regard to the management of indictments, this is an issue that is particularly problematic in the context of complex international criminal trials with reference to undue delay, thus affecting the right to a fair trial. Persons who are accused jointly of the same crime may be tried separately in order to avoid conflict of

\footnotetext{
141) Rules 89(F), 92bis and 92ter ICTY RPE and Rule 92bis ICTR RPE.

${ }^{142)}$ M Fairlie, 'The Marriage of Common and Continental Law at the ICTY and its Progeny, Due Process Deficit' (2004) 4 International Criminal Law Review 243.

143) G Higgins, 'Fair and Expeditious Pre-Trial Proceedings - The Future of International Criminal Trials' (2007) 5(2) JICJ 394.

144) Ibid, at 396.

145) Ibid, at 398.

146) Ibid, at 399.

147) Rome Statute Articles 67(2) and 54(1)(a) respectively. Note, however, that the duty to disclose is not without problems, as evidenced by the application to stay proceedings in the Lubanga case due to the fact that 'the trial process has been ruptured to such a degree that it is now impossible to piece together the constituent elements of a fair trial' (Prosecutor v Thomas Lubanga Dyilo 'Decision on the consequences of non-disclosure of exculpatory materials covered by Article 54(3)(e) agreements and the application to stay the prosecution of the accused, together with certain other issues raised at the Status Conference on 10 June 2008', 13 June 2008, ICC-01/04-01/06-1401, para 93).

148) Rome Statute Articles 56 and 57.

149) Rome Statute Article 68(3). See also J Jackson, 'Finding the Best Epistemic Fit for International Criminal Tribunals - Beyond the Adversarial-Inquisitorial Dichotomy' (2009) JICJ 7(1) 17.
} 
interests and protect the interest of justice. ${ }^{150}$ However, severance of charges or proceedings is subject to the consideration of several issues, including judicial economy, undue delay and the right to an expeditious trial. ${ }^{151}$ Despite the fact that the severance procedure aims at supporting the right to be tried without undue delay, it is also possible that this procedure could have the opposite effect, as evidenced by the severance procedure applied in the Duch case by the Extraordinary Chambers in the Courts of Cambodia (ECCC). ${ }^{152}$ In this case several factors - the length of the indictment (400 pages), the age and poor health of the defendants and the limited resources - led to the application of the severance procedure in the interest of justice. ${ }^{153}$ Nevertheless, the same procedure also led to complex challenges and uncertainties, not necessarily as a result of the severance procedure itself, but rather as a result of its poor execution. ${ }^{154}$ The important lesson to learn with regard to severance and judicial economy is that the wider spectrum of fair trial rights must be taken into consideration when applying this procedure, and judges should manage it in a 'careful and proactive' manner. ${ }^{155}$

\subsection{The application of judicial economy at the ICC}

To date, the ICC has applied the principle of judicial economy in a variety of settings, though there seems to be a prevalence of its use in the context of the confirmation of charges stage. For example, in order to distinguish cases that go to trial and cases that do not, Pre-Trial Chamber I in Prosecutor v Callixte Mbarushimana stated that the application of the standard of 'substantial grounds to believe', used for the purpose of confirmation of charges, ensures judicial economy. ${ }^{156}$ Likewise, in Prosecutor v Sang and Ruto, Pre-Trial Chamber II stated that the purpose of a determination under Article 61(7) of the Rome Statute is to protect suspects from wrongful prosecutions,

\footnotetext{
150) See Rules 2, 72, 73, 82(B) ICTY RPE; Rules 83(b), 72(a) ICTR RPE; Rule 136 ICC RPE.

151) Sluiter et al (eds.) supra note 138, at 532.

152) Agreement between the United Nations and the Royal Government of Cambodia Concerning the Prosecution Under Cambodian Law of Law Crimes Committed During the Period of Democratic Kampuchea, GA Resolution 57/228, 18 December 2002; Severance Order Pursuant to Internal Rule 89ter, Case 002, ECCC Trial Chamber, 22 September 2011 (hereafter 'Trial Chamber Severance Order'), para. 2.

${ }^{153)}$ Rule 89ter ECCC Internal Rules.

${ }^{154)}$ S Williams, 'The Severance of Case 002 at the ECCC - A Radical Trial Management Technique or a Step Too Far' (2015) JICJ 13(4) 815.

155) Ibid, 843.

156) 'Decision on the Confirmation of Charges', ICC-01/04-01/10, 16 December 2011, paras. 40 and 41.
} 
thus ensuring judicial economy by blocking unmeritorious cases to proceed to trial. ${ }^{157}$ Similarly, an investigation of evidence of alibi will not be carried out if there is not sufficient evidence of criminal responsibility, ensuring judicial economy and fairness of proceedings. ${ }^{158}$ Moreover, the evidentiary threshold itself, as set out in Article 61(7), is higher than the one required for the issuance of an arrest warrant or summons to appear, ${ }^{159}$ thus protecting the suspect against wrongful prosecution and ensuring the application of judicial economy by carefully selecting the suitable cases to proceed to trial. ${ }^{160}$

In the context of the efficient use of the Court's resources, ${ }^{161}$ the joinder or severance procedure in respect of charges ${ }^{162}$ also contributes to judicial economy. It allows witnesses to give evidence only once, thus minimising the impact of the proceedings on them, and avoids duplication of evidence. ${ }^{163}$ Moreover, the early disclosure of the main lines of defence to the prosecution allows the latter to address them properly as they present their case, thus promoting justice and judicial economy. ${ }^{164}$ These procedures ensure the fairness and speediness of the trial, whilst also protecting the rights of the victims and witnesses. ${ }^{165}$ In addition, the right to ask questions to witnesses at trial is laid down in the ICC Rules ${ }^{166}$ and inspired by judicial economy. ${ }^{167}$

In the light of the above examples, the Court appears to make use of the concept of judicial economy in a very narrow sense, and adopts it in very limited circumstances. The main issue with the Trial Chamber (B) discussion in the Kenyatta excusal decision is that the judges refused to engage with the principle of judicial economy. This would have been an excellent opportunity to integrate the principle within the

\footnotetext{
157) 'Decision of Confirmation of Charges Pursuant to Article 61(7)(a) \& (b) of the Rome Statute', ICC01/09-01/11, 23 January 2012, para 40.

158) Ibid, paras. 105 and 110.

159) The standard applied in these cases is the 'reasonable grounds to believe' as set out in Article 58(1) of the Rome Statute rather than the 'substantial grounds to believe' as set out in Article 61(7) of the Statute.

160) Prosecutor v Jean-Pierre Bemba Gombo, Pre-Trial Chamber II, ICC-01/05-01-08, 15 June 2009, para 28.

161) See, for example, the Report on Activities and Programme Performance of the International Criminal Court for the Year 2012, ICC/ASP/12/9, Proposed Programme Budget for 2014 of the International Criminal Court, ICC-ASP/12/10 (Twelfth Session, 20-28 November 2013, The Hague).

162) Article 64(5) of the Rome Statute and Rule 136 of the ICC Rules of Evidence and Procedure.

163) See ICC-01/04-01/07-257, Pre-Trial Chamber I, 10 March 2008, at 7-8.

164) See 'Decision on the Disclosure by the Defence', Prosecutor v Lubanga, Trial Chamber I, ICC01/04-01/06, 20 March 2008.

165) Article 64(2) of the Rome Statute.

166) Rule 140 ICC Rules of Procedure and Evidence.

167) R Cryer et al, An Introduction to International Law and Procedure (CUP, 2010), at 489.
} 
wider human rights framework. In fact, the manner in which the Chamber so readily dismissed the principle, leads to the conclusion that the ICC generally interprets judicial economy in a narrow sense only. This is in line with the examples cited above, which apply the principle of judicial economy as a filtering mechanism to ensure the Court proceeds with the prosecution of valid cases only.

\subsection{Undue delay and judicial economy in Mr Kenyatta's excusal decision}

In the Bemba case, ${ }^{168}$ it was stated that the expeditiousness of the trial is one of the factors that secures the fairness of the trial proceedings. This is what prompted the admission of all evidence, which in turn was said to contribute to the accused being tried without undue delay. ${ }^{169}$ However, both the defence and the prosecution appealed the decision on the basis that the expeditiousness in favor of the accused did not comply with the principle of orality, in accordance with Article 69 (2) of the Rome Statute. In fact, the Appeals Chamber reversed the Trial Chamber's decision on the basis that expeditiousness, whilst an important factor of fair trial, cannot trump a legislative provision. ${ }^{170}$ The Chamber emphasized that the principle of orality could be sidestepped only if such action was 'not prejudicial to or inconsistent with the rights of the accused or with the fairness of the trial generally', ${ }^{171}$ something that the Trial Chamber failed to examine. ${ }^{172}$

Accordingly, a procedure that leads to an expeditious trial - thus supporting the right to be tried without undue delay - does not necessarily imply that fairness is applied consistently across all participants to the proceedings. The right to be tried without undue delay exists within the overall principle of the right to a fair trial, and it therefore subsists within the overarching concept of fairness. In a sense, the right to be tried without undue delay tends to favor the accused, but fairness is a process that affects all participants in the criminal justice machinery. As stated above, ${ }^{173}$ fairness

\footnotetext{
168) Prosecutor v Jean-Pierre Bemba Gombo, ICC-01/05-01/08-1022, Decision on the admission of evidence of materials contained in the prosecution's list of evidence, 19 November 2010, TC III.

169) Ibid, para. 23; see also E Trendafilova, 'Fairness and expeditiousness in the International Criminal Court's pre-trial Proceedings' in C Stahn and G Sluiter (eds.) The Emerging Practice of the International Criminal Court (Martinus Nijhoff, 2009) at 441.

170) The Prosecutor v Jean-Pierre Bemba Gombo, ICC-01/05-01/08-1386, Judgment on the appeals of Mr Jean- Pierre Bemba Gombo and the Prosecutor against the decision of Trial Chamber III entitled 'Decision on the admission into evidence of materials contained in the prosecution's list of evidence', 3 May 2011, AC, para. 55.

171) Ibid, para. 78 .

172) Ibid, para. 79.

173) Supra, section 2.
} 
must be considered as an all-embracing egalitarian (procedural) and legitimacyenhancing value and, as the Bemba case demonstrates, one element of fairness (expeditiousness of the trial) should not be allowed to undermine other procedural elements or the general principle of fairness.

With this in mind, attention is drawn again to the assumption that the ICC Chamber moved forward with the proceedings in order to expedite the trial, in line with General Comment No. 13, namely that every stage of the proceedings must take place without undue delay. It was stated above that the right to trial without undue delay is affected by specific factors: complexity, conduct of the authority, conduct of the accused and prejudice suffered by the accused. ${ }^{174}$ As there was no discussion at all regarding the right to a fair trial or judicial economy, this author suggests that the best rationale for the Chamber's decision is that the accused, Mr Kenyatta, would have suffered prejudice if proceedings were to be temporarily paused. There is no suggestion that this specific stage of legal proceedings was particularly complex, a characteristic normally associated with a high number of charges, a huge amount of evidence and countless witnesses. ${ }^{175}$ Likewise, nothing in the conduct of the accused or the Court itself could provide any justification for an alleged violation of the right to a fair trial. If the accused is said to have suffered prejudice, then there must be some concrete evidence of human rights violations. ${ }^{176}$ In the case of Mr Kenyatta, there were no apparent violations, and therefore there did not seem to exist any logical explanation as to why the Trial Chamber did not see fit to wait for the Appeals Chamber decision on the same matter. The following two scenarios portray two different pictures:

\subsubsection{Scenario 1}

A reasoned discussion regarding the application of judicial economy would have revealed the necessity to carry out a balancing exercise: the Court's need to conduct its business in an efficient manner, against the defendant's right to be tried without undue delay. On balance, it is contended that a rational discussion would have

\footnotetext{
174) Supra, note 78.

175) See, for example, Prosecutor v Mugenzi and Mugiraneza, Appeals Judgment, Case no. ICTR-9950-A, 4 February 2013.

176) Prosecutor v Barayagwiza, Trial Chamber II 'Decision on the extremely urgent motion by the defence for orders to review and/or nullify the arrest and provisional detention of the suspect', Case No. ICTR-97-19-I, 17 November 1998 (the decision was later reversed by the Appeals Chamber, ICTR 9719-AR72, 3 November 1999).
} 
revealed that the accused was not going to suffer any prejudice, and efficiency therefore had to be prioritized.

\subsubsection{Scenario 2}

The complete lack of a reasoned discussion on the relevant issues led to inconsistency and disarray between Trial Chamber (B) and the Appeals Chamber. The Appeals Chamber reversed Trial Chamber (A) decision on excusal from attendance, and just before that reversal decision, Trial Chamber (B) decided to concur with Trial Chamber (A). There seems to be no explanation for this apparent misuse of resources.

\section{Concluding remarks}

The Chamber's outright rejection to engage with the principle of judicial economy demonstrated a real neglect for the wider picture. The international criminal justice machinery is still in its developing phase, and the ICC's prerogative is to ensure that its credibility and legitimacy is maintained throughout all its decisions. The Chamber's decision to proceed in such a hurried way lacked common sense. Moreover, the complete lack of a human rights perspective places the ICC in an awkward position regarding the interpretation and application of Article 21(3) Rome Statute and its mandate to uphold 'international human rights standards'.

As a final note, this author is mindful of the fact that the defendant in this particular case was the sitting President of Kenya, and the ICC prosecutorial office must indeed be commended for its efforts to pursue a prominent state official for the crimes (he allegedly) perpetrated in Kenya. ${ }^{177}$ We must remind ourselves that in the history of international criminal law this is the first time that such a prosecution is attempted against a sitting president. ${ }^{178}$ It is specifically for this reason that the ICC must be

\footnotetext{
177) For a discussion on the immunity of heads of state see MM Penrose, 'It's Good to Be the King!: Prosecuting Heads of State and Former Heads of State Under International Law' (2000) 39 Columbia Journal of Transnational Law 194; S Zappalà, 'Do Heads of State in office enjoy immunity from jurisdiction for International Crimes? The Ghaddafi Case before the French Cour de Cassation' (2001) 12(3) EJIL (2001) 595; MA Summers, 'Immunity or Impunity?: The Potential Effect of Prosecutions of State Officials for Core International Crimes in States like the United States that are not Parties to the Statute of the International Criminal Court' (2005-2006) 31(2) Brooklyn Journal of International Law 463.

178) See GP Barnes, 'The International Criminal Court's Ineffective Enforcement Mechanisms: The Indictment of President Omar Al Bashir' (2010-2011) 34(6) Fordham International Law Journal 1584. Although arrest warrants have been issued against Mr Al Bashir, President of Sudan, he still remains a free man in his own country; he has not been arrested nor has he ever voluntarily appeared at the ICC to face the charges against him (see Prosecutor v Omar Hassan Ahmad Al Bashir, ICC-02/05-01/09,
} 
thorough in the way it deals with the trial of a sitting president, as the lack of a transparent discussion may be misinterpreted as an attempt to undermine what is supposed to be a rigorous judicial process.

In fact, given the alleged claims concerning bribes and threats surrounding the witnesses in Mr Kenyatta's prosecution, ${ }^{179}$ the dismissal of a discussion on judicial economy may weaken the Court's legitimacy and its mandate to uphold wellrecognised procedural principles. Fairness cannot be evaluated properly when an important discussion has been disregarded in the course of the judicial process, as it gives the impression of bias, either in favour and against the accused. After all, the suggestion that the ICC is an 'African Court' must be dispelled, ${ }^{180}$ rather than fuelling antipathy between Kenya and the ICC. ${ }^{181}$

It is conceivable that the ICC may never get the opportunity to prosecute a sitting president again. Just like the current case of Mr Laurent Gbango, ${ }^{182}$ any future head of state appearing at the ICC as a defendant is likely to have lost an election or have resigned by the time the arrest and surrender to the ICC takes place. Clearly the symbolism about impunity accompanying the prosecution of a sitting president is astounding, and that message must not be underestimated. Nevertheless, it is vital that any issues in relation to procedural fairness are properly discussed and evaluated, though it is equally important that the evidence gathered at the initial investigative

Pre-Trial Chamber I, First Arrest Warrant issued on 4 March 2009, Second Arrest Warrant issued on 12 July 2010). Also, with regard to Charles Taylor, he was still the appointed Liberian President when the Special Court for Sierra Leone issued the indictment (March 2003). However, after much pressure from other African leaders, he resigned in August 2003 and went to Nigeria in exile; it was at this stage that an international arrest warrant was issued by Interpol and, following an arrest warrant issued by the Liberian president, he was arrested by the Nigerian police; See CC Jalloh, 'The Law and Politics of the Charles Taylor Case' (2014-2015) 43(3) Denver Journal of International Law \& Policy 229. The trial of Laurent Gbagbo, former president of the Côte d'Ivoire, is due to start in November 2016. At the time of his arrest in 2011 he had lost the presidential election (Alassane Outtara's victory was recognized by the UN, the EU and the United States), even if the Constitutional Council named him as the winner, which led to the civil unrest and violence.

179) See 'ICC drops Uhuru Kenyatta charges for Kenya ethnic violence', 5 December 2014 at <http://www.bbc.co.uk/news/world-africa-30347019> accessed 17 November 2015.

${ }^{180)}$ See M Delmas-Marty, 'Ambiguities and Lacunae: The International Criminal Court Ten Years on' (2013) 11(3) JICJ 553.

${ }^{181)}$ In fact, both the Kenyan Parliament and prominent officials have issued statements regarding the possible withdrawal from the ICC. Also, the African Union has taken retaliatory measures against the ICC; see CB Murungu, 'Towards a Criminal Chamber in the African Court of Justice and Human Rights' (2011) 9(5) Journal of International Criminal Justice 1067; A Abass, 'The Proposed International Criminal Jurisdiction for the African Court: Some Problematical Aspects' (2013) Netherlands International Law Review 60(1) 27.

182) Warrant of arrest for Laurent Koudou Gbagbo, ICC02/11, November 2011; Decision on the confirmation of charges ICC 02/11-01/11, 12 June 2014. 
phase is sufficiently robust to ensure a trial of this nature does not end up in a complete failure. ${ }^{183}$

As a final comment on the fairness of trials at the ICC, the recent events concerning the collapse of the trial in the case of Mr William Samoei Ruto and Mr Joshua Arap Sang makes for a timely addition to this article. On 5 April 2016 the ICC Trial Chamber decided to vacate all charges against the accused due to unreliable evidence. ${ }^{184}$ More specifically, the Chamber granted the motion by the two accused that there is no case to answer. The Ruto defence, for example, claimed that the evidence was insufficient and deficient, and most importantly they claimed that the Prosecution fundamental flaw was its inability to link him (Mr Ruto) to the 'Network' for the purposes of forming part of an organisation in order to satisfy the requirements of crimes against humanity. ${ }^{185}$ Given the turn of events in the Kenyatta trial, which was also affected by problems in relation to the reliability of witnesses, as well as Kenya's cooperation with the ICC, the conclusion of the trial of Mr Ruto and $\mathrm{Mr}$ Sang is not completely surprising.

Before commenting on the main judgment, the dissenting opinion of Judge Herrera Carbuccia ${ }^{186}$ provides a useful backdrop to the general discussion on fairness at the ICC. She did not agree with the majority's decision and believed that a 'reasonable Trial Chamber' could convict the accused. ${ }^{187}$ She also reiterated that the concept of fairness should be interpreted widely, because it is relevant to all parties; in this context, her assertions echoed the wider meaning of fairness discussed in this article:

I believe that the duty of the Chamber is to ensure a fair and expeditious...However, the right to a fair trial must be interpreted in a flexible and comprehensive manner, as fairness pertains to all parties: on the one hand the accused, and on the other, the Prosecutor, who acts on behalf of the international community, including the victims. ${ }^{188}$

\footnotetext{
${ }^{183)}$ Steven Kay QC, The Prosecution of Uhuru Kenyatta at the International Criminal Court (January 2015) 〈http://www.internationallawbureau.com/wp-content/uploads/2015/01/report.pdf $>$ accessed 20 November 2015); see also The Times Newspaper letter acknowledging some serious journalistic mistakes in the reporting of the facts in the Kenyatta case, at 〈http://www.internationallawbureau.com/index.php/author/steven-kay/> accessed 20 November 2015. 184) Prosecutor v William Samoei Ruto And Joshua Arap Sang, Decision on Defence Applications for Judgments of Acquittal, ICC-01/09-01/11, 5 April 2016 (henceforth Ruto and Sang Acquittal).

${ }^{185)}$ Ruto Defence Motion, ICC-01/09-01/11-1990-Corr-Red, paras. 197-198.

186) ICC-01/09-01/11-2027 Annex I.

187) Ibid, para. 2.

188) Ibid, para. 27.
} 
More importantly, in the following passage she also noted the need to attain a balancing exercise between the principle of expeditiousness and the right of the accused to be tried without undue delay, and in this context

Judges should not only seek to find what the parties assert. They also need to determine the truth, and in their task '[i]nterpretation may then not only be about finding what the parties wanted, but also what interests the community, what is required by human rights, or what is morally the best answer. ${ }^{189}$

In the light of the approach taken by Judge Carbuccia, confirming the centrality (and expansive meaning) of the concept of fairness, it is somehow unexpected that the main judgment introduced a notion that does not feature at all in the ICC Rome Statute or the Rules of Evidence and Procedure, namely a 'mistrial'. In the opinion of presiding Judge Chile Eboe-Osuji, a mistrial had to be declared because of a 'troubling incidence of interference with witnesses or undue meddling from an outside source, that is capable of prejudicial impact on the case'. ${ }^{190}$ Judge Fremr did not use the actual word 'mistrial' but stated instead that he did 'not consider the impact to have been of such a level so as to render the trial null and void' ${ }^{191}$.

Furthermore, Judge Eboe-Osuji specifically indicated that Article 64(2) supports the power to declare a 'mistrial', a power further reinforced by the 'doctrine of incidental or implied powers under international law, ${ }^{192}$ and therefore not limited by the 'applicable law' set out in Article 21. ${ }^{193}$ In fact, the interpretation adopted by Judge Eboe-Osuji in the context of the right to a fair trial deserves some further analysis, which is beyond the scope of this article. However, as a concluding remark, it is significant that Judge Eboe-Osuji insisted in the adoption of a teleological interpretation in order to achieve fairer results for all participants. He asserted that the adoption of a 'broad and liberal construction to maximise protection of beneficiaries ${ }^{\text {'194 }}$ should not just apply to human rights and humanitarian law, but also

\footnotetext{
189) Ibid, para. 28. An example of the implication of this dictum can be found in the context of sexual violence perpetrated during the Rwandan genocide, which led to the landmark judgment of Prosecutor v Akayesu, Case No. ICTR-96-4-T, Judgment, 2 September 1998.

190) Ruto and Sang Acquittal, para. 7.

191) Ruto and Sang Acquittal, para. 147.

192) Ruto and Sang Acquittal, Judge Eboe-Osuji, para. 191.

${ }^{193)}$ Ruto and Sang Acquittal, Judge Eboe-Osuji, para. 192.

194) Ruto and Sang Acquittal, Judge Eboe-Osuji, para. 326. The phrase 'broad and liberal construction to maximise protection of beneficiaries' is taken from D Robinson, 'The Identity Crisis of International Criminal Law’ (2008) 21(4) Leiden Journal of International Law 925.
} 
to criminal law, as, ultimately, 'those beneficiaries are both victims of crimes and persons accused of crimes'. ${ }^{195}$ In other words, the wider scope attributed to the concept of fairness, as seen in the dissenting opinion by Judge Carbuccia, is again reiterated by Judge Eboe-Osuji, leading to a controversial new concept in international criminal proceedings.

${ }^{195)}$ Ruto and Sang Acquittal, Judge Eboe-Osuji, para. 327. 